\title{
A century of Futurist Architecture: From Theory to Reality
}

\author{
Farhan Asim \\ M.Arch Student (Sustainable Architecture) \\ NIT Hamirpur, India \\ +91-8948318668 \\ beyondfarhan@gmail.com
}

\author{
Venu Shree \\ Assistant Professor \\ NIT Hamirpur, India \\ +91-7018620827 \\ venushree80@gmail.com
}

\begin{abstract}
The Italian Architect Antonio Sant'Elia is considered the father of Futurist Architecture, the one who envisioned the future of cities on the basis of the native population's work culture and habitual traits. It has been a century since his ideas were introduced in his 'L-Architettura Futurista - Manifesto' and later circulated by F.T. Marinetti, today they are making a prodigious impact on the architecture style of the entire world. His revolutionary ideas percolated through the murky aftermath of 19th \& 20th century art movements. His out-worldly pre-modernist principles gave rise to the notion of exclusive habitats for generations and started the post-war trend of housing typologies as an industrialized and fast track medium of creating ample habitats. This review paper outlines the ideas and design theory of Antonio Sant'Elia through the advancements and achievements of the 20th \& 21st century architects and their significant difference with the rest of historical architecture along with identification of elements of futurist principles in different architectural movements. The paper also makes a deliberate attempt to establish a timeline of developments within the said premise for futurist architecture.
\end{abstract}

Keywords: Futuristic Architecture; Neo-futurism; Deconstructivism; Modernism; Antonio Sant' Elia.

\section{INTRODUCTION}

The term 'Futuristic Architecture' gained momentum from the $20^{\text {th }}$ century art and social movement called 'Futurism'. Futurism is the first internationally recognized modern art movement to emerge out of a united Italy [1]. It had inclination towards high speed, advancements in technology, role of youth in society, and associated violence. The introduction of transportation features like cars \& aircraft into the society brought fascination into the lives. It gave them the idea of life around such compelling mediums in the form of industrial cities. The degree of fascination can be observed in Italian poet Marinetti's (1909) 'Manifesto of Futurism', where he addressed people, "We affirm that the world's magnificence has been enriched by a new beauty: the beauty of speed. A racing car whose hood is adorned with great pipes, like serpents of explosive breath - a roaring car that seems to ride on grapeshot is more beautiful than the Victory of Samothrace" [2].

Antonio Sant'Elia and Mario Chiattone participated in 'Nuove Tendenze' i.e., New Trends in 1912 in Milan, Italy. Sant'Elia worked on futurist architectural principles and exhibited them in 1914 with F.T Marinetti titled - 'LArchitettura Futurista - Manifesto' i.e., Manifesto of Futurist Architecture. Several other deliberate attempts were made by artists and architects like Virgilio Marchi, Ottorino Aloisio, Luigi Colombo, Angiolo Mazzoni and Mino Somenzi to consolidate the specific ideas of futurism for art \& architecture [3].

\section{Futuristic ARCHITECTURE: IDEAS, ORIGIN \& FAtE}

The new generation of futurists hypothesized about the vision for new metropolises and megalopolis with flexible and more useful urban environments. The AvantGarde ideas of futurists stayed as an inherent part of modern architectural edification. The futurist idea of development was to disregard history and come up with new ideologies and structure that could formulate the future cities and neighborhoods [3]. Futurism as an artistic movement repudiated use of traditional forms and adopted the revolutionary impulse regarding possibilities that technology could revive and amplify culture, dilapidated lifestyle and the condition of cities [5]. In 1912, Sant'Elia started an architecture design office with his associate Chiattone, where he formulated his groundbreaking utopian vision for the future in the form of sketches that would have a fervent ascendancy in Modernism [9].

Sant'Elia worked at the core of a fast-paced metropolis that was experiencing some cardinal developments which created mass issues of industrial \& population growth. He envisioned a magnificent futurist city called 'Citta Nuova' i.e., New City. The city of his ideas comprised of monolithic and Herculean skyscrapers along with bridges \& pedestrian walkways that bisected the sky [8]. Lamentably, 13 futurists including Antonio Sant'Elia were killed in the First World War [6]. Sant'Elia died in 1916 at the 'Eighth Battle of the Isonzo', and not even a single of his designs ever turned into a building. The same fate was shared by drawings of Mario Chiattone, who was the associate of Sant'Elia. The duo had exhibited a systematic approach to city design that matched Le Corbusier's later profound quote "The house is a machine for living in". Virgilio Marchi was another architect and set designer for motion pictures whose work ideas coincide well with that of Antoni Gaudi, but his modernist utopian vision was also never constructed as buildings or cities [4]. Futurist ideas propagated far into Russian soil and influenced Mayakovsky and Malevich. The futurist movement's credibility was expropriated when Marinetti began to use Futurism as a Fascist movement [10].

\section{THE MANIFESTO -1914}

"No architecture has existed since 1700. A moronic mixture of the most various stylistic elements used to mask the skeletons of modern houses is called modern architecture." In the opening sentences of his paper which was published in two parts as a leaflet in Lacerba (Florence) in 1914, he does not 
seem to be very delighted with the then definition of modern architecture \& the overly glorified use of Neoclassicism, which he has objected to and called it alien to the native region of Europe as they belong mostly to Egyptian, Indian and Byzantine [7].

"We must invent and rebuild the Futurist city like an immense and tumultuous shipyard, agile, mobile and dynamic in every detail; and the Futurist house must be like a gigantic machine." - It can be deduced from the kind of urge Sant'Elia created with the choice of his words in his most celebrated text 'Manifesto of Futurist Architecture' that he has envisioned a distance future which can only be achieved if the ways of architecture are bent towards the experimental yet possible feats in coordination with most advanced technology. He made it very subtle what he likes and dislikes about the then contemporary architecture. His paper had a satirical tone where he criticized the Italian Architects for creating 'hilarious salad' of seventeenth century monumental architectural details and ornamentation in the new quarters of the modern world towns. The young Architects' refusal to move ahead of the age of works of Vitruvius, Vignola and Sansovino along with the then current trends from multiple sources of German Architecture is termed a foolish attempt [7].

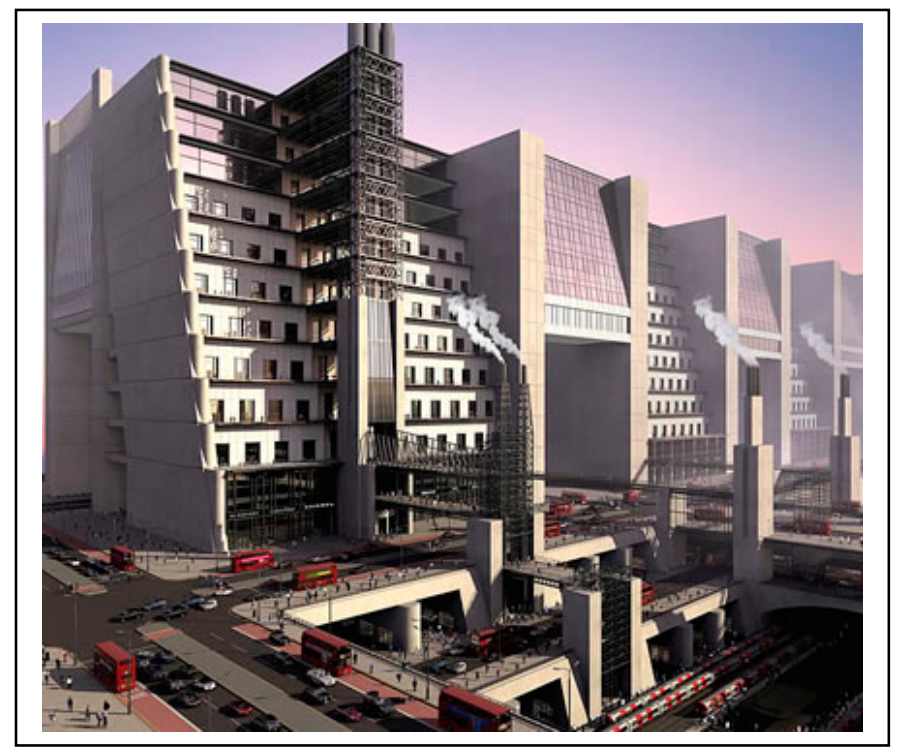

Figure 1. Computer visualization of one of Sant'Elia sketches

(Source: Atkinson+Co, East London)

According to Sant'Elia, the major contrast between the modern world and the previous one is determined by all those things which didn't exist in the past. Architecture and society has seen a major shift in its applicability from grand cathedrals, palaces to the 'great hotels, railway stations, immense streets, colossal ports, covered markets, luminous arcades, straight roads and beneficial demolitions', if needed. This major shift can be broadly seen as change of attitude from traditional, cultural and religious preferences towards more social and public spaces. Sant'Elia's vision for a futurist city is mobile and dynamic in every detail; he even gave the very first impression of House being a giant machine with technology being on the front staying exposed like lifts, stairwells nourished by concrete, glass and steel. In the 2nd part of the published paper, he urges the abolition of decorative elements which are stolen from Chinese, Persian or Japanese Architecture and also the overuse of Vitruvian principles. The efficient and revolutionized use of roofs and underground spaces was suggested and the demise of monumental and commemorative architecture was expected from the younger generation of architects to raise the level of the city [7].

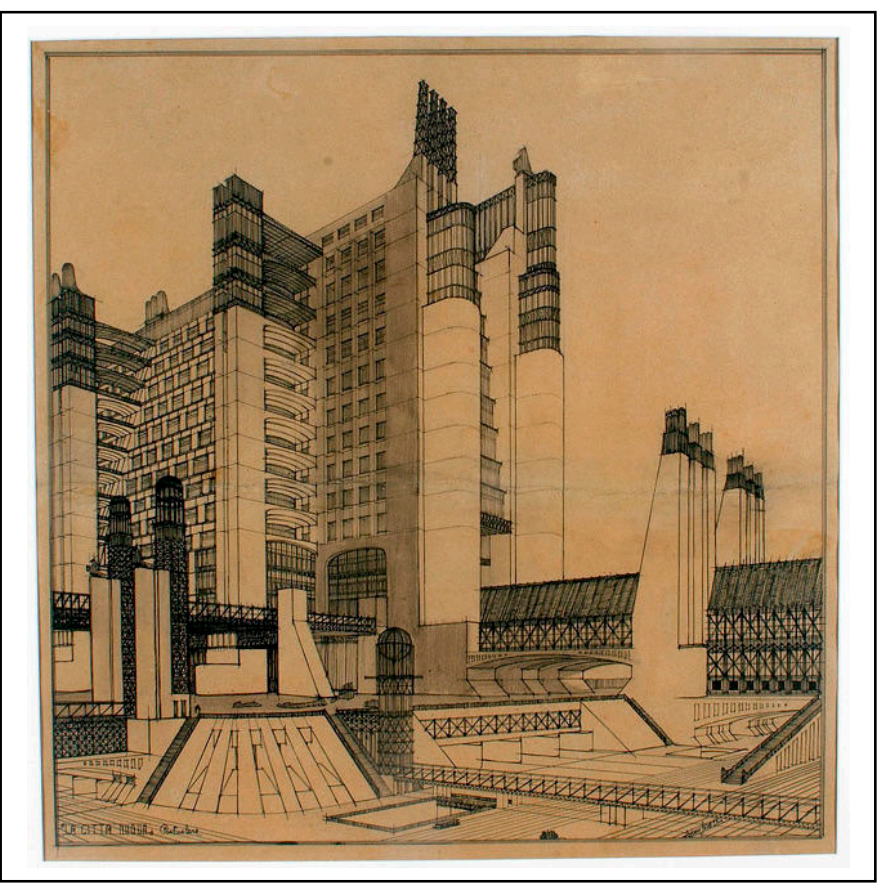

Figure 2. Antonio Sant' Elia sketch - Housing with external lifts and connection systems to different street levels from La Città Nuova, 1914.

(Source: Wikimedia Commons)

He introduced 'Futuristic Architecture' as the architecture of calculation, of bold and risky and of simplicity. The architecture of materialistic substitutes of wood, stone and brick which can help us achieve maximum elasticity and lightness apart from the continued reliance on steel, glass, cardboard and textile fiber.

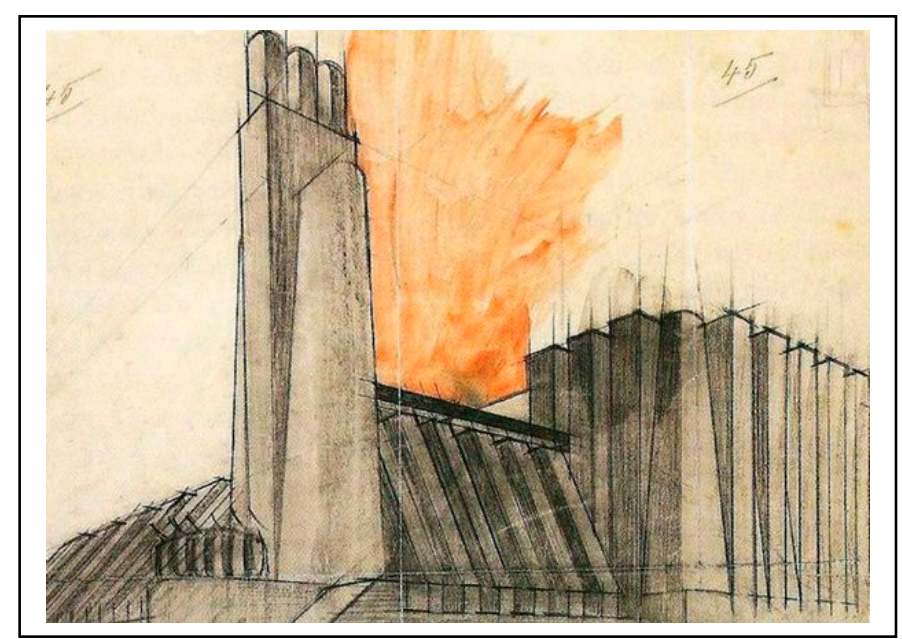

Figure 3. Antonio Sant' Elia sketch - La Città Nuova, 1914.

(Source: Wikimedia Commons)

He foresaw the future of oblique and elliptical lines as more dynamic and stronger than perpendicular and horizontals. He favored the use of violently colored materials and abolition of superimposition of decoration on original forms and often discredited the definition of architecture as just an arrangement 
of forms. In his vision, the Futuristic city had to be impermanent and transient [7].

\section{TIMELINE OF $20^{\mathrm{TH}}$ CENTURy ARCHITECTURE MOVEMENTS}

Table 1. Table example

Movement

Duration

\begin{tabular}{l|l|}
\hline Futurist Architecture & $\mathbf{1 9 1 0}$ - 1945 \\
\hline Art Deco & 1910 - 1940 \\
\hline Bauhaus & $1920-1934$ \\
\hline Surrealist Architecture & $1925-1930$ \\
\hline Streamlining & $1930-1950$ \\
\hline Organic Architecture & $1930-1960$ \& 1990 - Present \\
\hline Scandinavian Modern & 1935 - Present \\
\hline Contemporary Architecture & $1945-1960$ \\
\hline Googie Architecture & $1947-1965$ \\
\hline Pop Art Architecture & 1958 - 1972 \\
\hline Space Age & 1960 - 1969 \\
\hline Neo-futurism & 1966 - Present \\
\hline Minimalism & $1967-1978$ \\
\hline Post Modernism & 1978 - Present \\
\hline Memphis & 1981 - 1988 \\
\hline Deconstructivism & 1988 - Present \\
\cline { 2 - 2 } &
\end{tabular}

Not all the architectural and art movements got desired attention and approval from general masses. However, some movements although short-lived left an impact on the other styles which later evolved. The next segment outlines some selective architecture movements which went parallel or within the premise of Futurist Architecture.

\section{FUTURISTIC ARCHITECTURE: EVOLUTION FROM FUTURISM}

The evolution segment of this paper covers only the architectural movements which were relevant in the premise of Futuristic Architecture.

\section{A. Art Deco}

Art Deco got its name from the 'Arts Décoratifs'- The International Exhibition of Modern Decorative and Industrial Arts held in Paris in 1925. It served as the combination of modernism with eloquent materials and fine craftsmanship. It was under heavy influence of the dauntless geometric patterns of Cubism and the sharp colors of Fauvism. Art Deco was considered a futuristic style in 1920 s and 1930s due to its streamlined use of delicate forms. According to Royal Institute of British Architects (RIBA), "The clean lines and minimal decoration of this style was associated with entertainment and glamour." One of the most profound examples of Art Deco are the Chrysler Building by Architect William Van Allen and the American Radiator building by Raymond Hood in New York City [11]. Art Deco was first used for public and commercial buildings in the 1920s. It was a rare case for individual homes to be designed in this style. Architects of Washington DC were the first to adopt the style in apartment buildings. Most of the Art Deco buildings of New York and Washington DC have now earned the status of Heritage Buildings due to their rich artistic features [12].

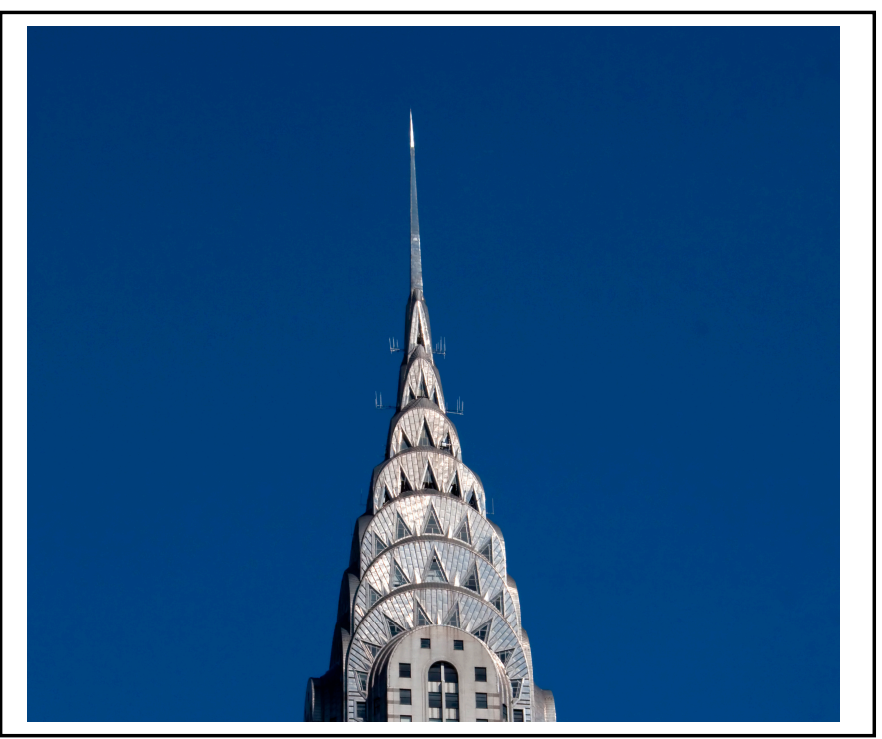

Figure 4. Chrysler Building (1930) by William Van Allen, New York City

$$
\text { (Photograph by Tony Hisgett) }
$$

Significance of an Art deco building [13]:

- $\quad$ Streamlining

- Bold shapes

- Colour

- Decoration

- Geometric designs

\section{B. Bauhaus}

Bauhaus architecture originated in Germany in 1920s under Walter Gropius and gained momentum later in United States in 1930s. Due to the Nazi influence in Germany, the pioneers of Bauhaus like Gropius, Mies van der Rohe and others moved to the U.S. and since then the American style of Bauhaus was accepted as the International Bauhaus movement [24].

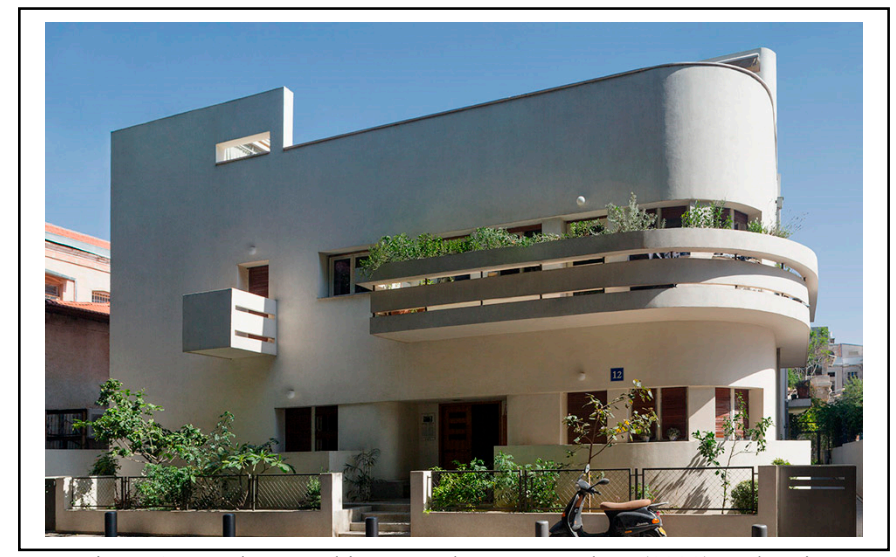

Figure 2. Avraham Soskin House by Zeev Rechter (1933), Tel Aviv (Photograph by Mikaela Burstow) 
Tel Aviv holds the richest collection of International Style Bauhaus buildings in the entire world. Approximately 4000 Bauhaus styled buildings were built in Tel Aviv between 1920 - 1940. Bauhaus gained significant momentum in Tel Aviv because the 17 former students of Bauhaus started practicing as Architects in the city, reframing and refining the localities in the new style with latest addition of materials [25].

Characteristics of International Bauhaus Style of architecture [24]:

- It avoids ornamentation and focuses on the functionality of the building.

- Prefers asymmetrical forms and shapes over regularized symmetry.

- It draws the contrast between space and mass in architectural context.

- Buildings adopt a cubic form.

- Prefers right angles (as opposed to Sant'Elia's other notion).

- Smooth and curvilinear finishes are induced.

\section{Googie Architecture}

Soon after the $2^{\text {nd }}$ World War, the fascist version of futurism was brought down and futurism as a whole lost its momentum. It was only revived as a new form i.e., 'Googie Architecture' in the late 1940s due to the growing interest towards car oriented world, space race, atomic race and jet age futurism [14]. Googie thrived until 1960 as it was favored in designs of moving-public utilities such as gas stations, motels, restaurants, cafes, etc. It earns its name from a café in Hollywood (L.A., California) designed by Architect John Lautner in 1949 and propagated by Architect Elton Davis [15] [16]. The term 'Googie' was first used by Architecture critic Douglas Haskell to identify the architectural style. Googie speaks of exaggeration and use of dramatic angles with materials like steel and plastic coupled with the fascination of neon.

Haskell argues, "You underestimate the seriousness of Googie. Think of it! - Googie is produced by architects, not by ambitious mechanics, and some of these architects starve for it. After all, they are working in Hollywood, and Hollywood has let them know what it expects of them" [16].

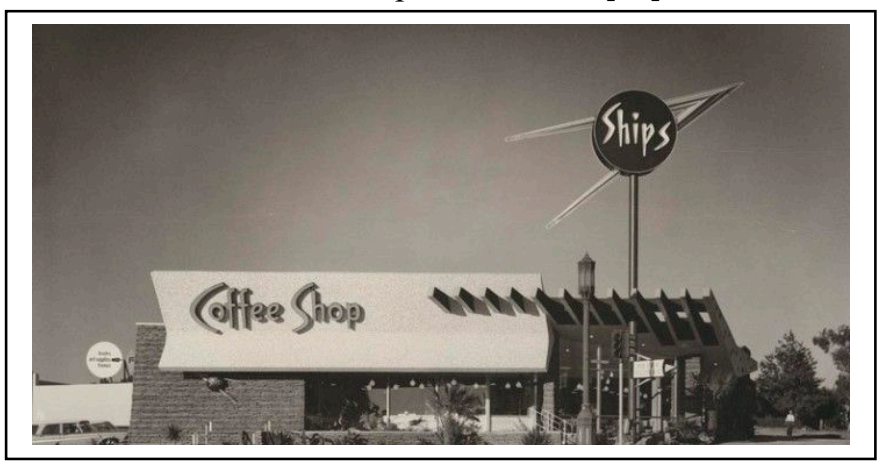

Figure 3. Ships Coffee Shop by Martin Stern Jr. (1963), Culver City (Photograph by University of Nevada, Las Vegas Libraries)
- $\quad$ Starbursts

- Roofs sloping at an upward angle

- Hard angles

\section{Neo-futurism}

To create a clear distinction between the futurist architecture of 1910-1920 and the architecture of post 1950s, futurism was renamed as 'Neo-futurism' by French Architect Denis Laming, who designed Futuroscope (a theme park rich in multimedia, cinematography \& audio-visuals) [23]. Neofuturism is also called Post Modern Futurism or Neo-Futuristic architecture. Neo-futurism speaks of all of futurist architecture built since late 1960s. It has a long list of Architects who practiced it and the impact is a worldwide phenomenon from Eero Sarinen's TWA Terminal at New York's J.F.K. Airport to Museum of Tomorrow in Rio de Janeiro by Santiago Calatrava [18][19]. Some of the most prominent pioneer Architects of Neo-futurism are Eero Sarinen, Alvar Alto, Buckminster Fuller, Le Corbusier, Santiago Calatrava, Michael Graves, Zaha Hadid, Oscar Neimeyer and Tadao Ando [20][21].

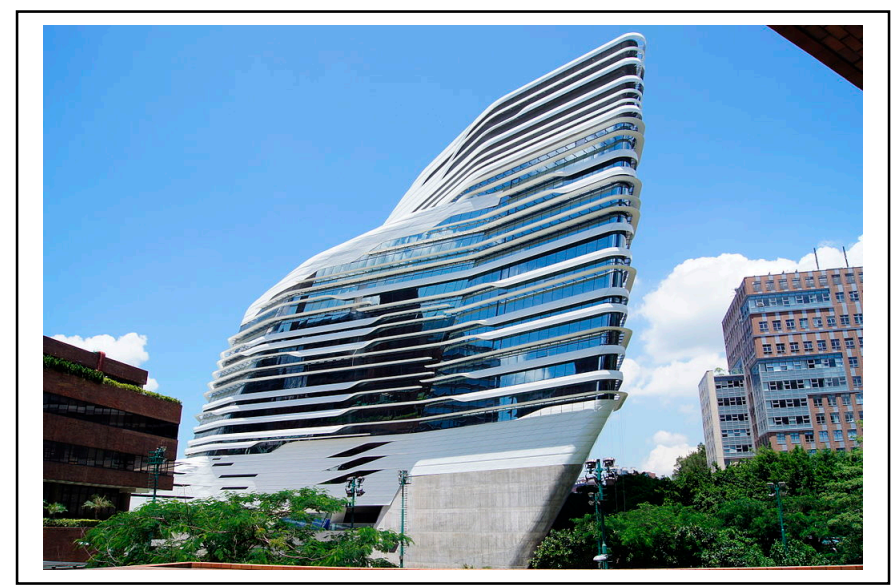

Figure 4. Jockey Club Innovation Tower by Zaha Hadid (2013), Hong Kong

(Photograph by Sebastian Wallroth)

According to Jean-Louis Cohen, Neo-futurism is a repercussion of technology, which uses most advanced available resources to make the future possible. Etan J. Ilfeld expressed that neo-futurist designs work on such complicated mediums that would have been impossible before the computer age [22].

\section{Significance of Neo-futurism in Architecture:}

- The style is based on precision to fortify the maximum degree of flexibility and frivolousness within the materials.

- It uses the architect's determination to bring abstract and decorative sense in the design.

- $\quad$ Futuristic buildings are supposed to last only for a short period of time as the style believes in the idea that all generations must dream and build their own cities. This idea goes parallel with the original impulse of Sant'Elia.

Significance of a Googie building [17]:

- Cantilevered roofs 
- $\quad$ Futuristic buildings can be called futuristic as long as they are updated regularly with the latest and most suitable technology.

- Advanced use of materials in design elements like a glass cladded façade, lightweight aluminum construction, and structural steel supports for enhanced and durable performance.

- The variety of buildings in this realm is unrestricted and minutely uncharted. Hence, it offers an abundance of exploration for Architects.

\section{E. Deconstructivism}

Deconstructivism originated in 1982 through a competition entry by Jacques Derrida and Peter Eisenman, the competition was however won by Bernard Tschumi [26]. Neo-futurism and Deconstructivism are linked with each other in such a way that it becomes difficult to determine where to draw the line of their differential aspects. Deconstructivism relies on Computer aided design (CAD) to visualize various forms and tendencies of the material and design elements. It opposes the established periphery of modernism and post-modernism in terms of rationality.

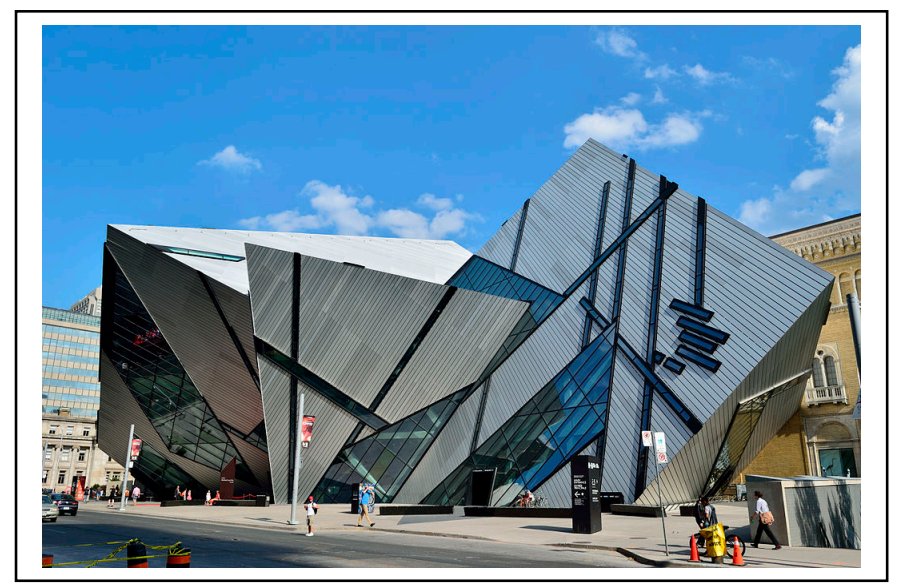

Figure 4. Royal Ontario Museum by Daniel Libeskind (2007), Hong Kong (Photograph by Raysonho)

Characteristics of Deconstructivism [28]:

- It proposes fragmentation in design.

- Utilizes the exterior of the building.

- Curvilinear and pointeds shapes are dominant, which are expected to keep the skeleton in a dynamic state.

- The building structure has an organized order of chaos and restorative unpredictability.

Some of the prominent architects of Deconstructivism are Frank Gehry, Bernard Tschumi, Zaha Hadid, Peter Eisenman, Rem Koolhaas, Daniel Libeskind and Vlado Milunić.

\section{CONCLUSION}

In an attempt to draw clear comparison between Sant'Elia's ideas in 1914 to the architectural achievements in early $21^{\text {st }}$ century, it is observed that futurist architecture although in continuous practice since late 1960s has only recently been able to meet up with Sant'Elia's expectations. With pioneers like Daniel Libeskind, Frank Gehry, Rem Koolhaas and Bjarke Ingels (the latest addition into the list whose ' 8 house' design matches Sant'Elia's dream of futuristic neighborhood), it is evident that futurist architecture has a long journey to cover as it is a mere reflection of 'the generation and its needs coupled with the technological advancements' [27].

\section{REFERENCES}

[1] Gardini A. The legacy of Antonio Sant'elia: An analysis of Sant'elia's posthumous role in the development of Italian Futurism during the Fascist era. San Jose State University; 2014.

[2] Marinetti FT. The futurist manifesto. Le Figaro. 1909 Feb 20;20:39-44.

[3] Linardi S. Virgilio Marchi, Antonio San't Elia, Mario Chiattone : Italian Futurism [Internet]. Simondlinardi.blogspot.com. 2014

[4] McKever R. Back to the futurism. The Art Book. 2010 Feb 1;17(1):66-7.

[5] McGarrigle N. The Futurist world of architect Antonio Sant'Elia [Internet]. The Irish Times. 2016

[6] Goldberger P. ARCHITECTURE: ANTONIO SANT'ELIA. New York Times Archives [Internet]. Nytimes.com. 1986

[7] Sant'Elia A. Manifesto of Futurist Architecture [Internet]. EVOLUTIONARY URBANISM. 1914

[8] Collins GR. Visionary drawings of architecture and planning: 20th century through the 1960s. Art Journal. 1979 Jun 1;38(4):244-56.

[9] Pierce JS. Architectural Drawings and the Intent of the Architect. Art Journal. 1967 Sep 1;27(1):48-59.

[10] Futurist architecture - Antonio Sant'Elia (1914) | Architecture Lab [Internet]. Architecture Lab. 2014

[11] Frampton K, Futagawa Y. Modern architecture. ADA Edita; 1983.

[12] Wentworth I. Art Deco Style (1925-1940). Wentworthstudio.com. 2018

[13] Waters S. Art Deco: an architectural style guide. British Architectural Library. RIBA. Architecture.com. 2017

[14] Haskell D. Googie Architecture. House and Home. 1952 Feb;1:86-8.

[15] Nelson V. Los Angeles Times - Eldon Davis dies at 94; architect designed 'Googie' coffee shops. Latimes.com. 2011

[16] Novak M. Googie: Architecture of the Space Age. Smithsonian. 2012

[17] Barragan B. An introduction to Googie, SoCal's signature architectural style. Curbed LA. 2018

[18] Román A, Saarinen E. Eero Saarinen: An architecture of multiplicity. Princeton architectural press; 2003.

[19] Bogunovich D, Wagner C. Showcasing green urbanism on waterfronts: A comparative study of Porto Alegre and Auckland. 2010.

[20] Markus V. Design Spotlight: Alvar Aalto- Travel Squire. Travel Squire.

[21] Montgomery A. Zaha Hadid building is 'best design of the year'. Design Week. 2014

[22] Neo-futurism - Designing Buildings Wiki. Designingbuildings.co.uk. 2017

[23] Allen E. The 8 Best Diamond-Inspired Architecture Around the World | Architectural Digest. 2017

[24] Zisling Y. Bauhaus Architecture. Jewishvirtuallibrary.org. 2018

[25] Howarth D. 10 of Tel Aviv's best examples of Bauhaus architecture. Dezeen. 2016

[26] Eisenman P, Derrida J. Chora L works. Monacelli Press; 1997.

[27] Ingels B, Ginsberg E, Pahhota D, Zahle D, Johansson H, Pedersen A, Bergman KU. Yes is more: An archicomic on architectural evolution. 2009.

[28] Proudfoot PR. Deconstructivism and Architectural Science. Architectural Science Review. 1991 Jun 1;34(2):55-63. 